\title{
Building evidence on effective programs to delay marriage and support married girls in Africa
}

Population Council

Follow this and additional works at: https://knowledgecommons.popcouncil.org/departments_sbsr-pgy

Part of the Demography, Population, and Ecology Commons, Family, Life Course, and Society Commons, and the International Public Health Commons How does access to this work benefit you? Let us know!

\section{Recommended Citation}

"Building evidence on effective programs to delay marriage and support married girls in Africa," brief. Addis Ababa: Population Council, 2014. 


\section{BUILDING EVIDENCE ON EFFECTIVE PROGRAMS TO DELAY MARRIAGE AND SUPPORT MARRIED GIRLS IN AFRICA}

\section{'Child marriage' is defined as marriage that occurs before the age of 18 (UNICEF 2001). The practice remains prevalent in many 'hotspots' of sub- Saharan Africa, including regions where marriage among girls during early adolescence (before age 15) is still very common (UNFPA 2005).}

On the continent, places where child marriage persists are mainly rural and frequently characterized by high rates of poverty, low levels of development, and limited schooling and work opportunities.

Girls married early are distinctly disadvantaged. They usually enter marriage with low levels of education and limited knowledge and skills needed to negotiate adult marital roles (UNICEF 2011). A recent study in Ethiopia found that 78 percent of girls married before age 15 have no education, indicative of the very limited skills and capabilities of girls who are married at the youngest ages (Erulkar 2013). Girls married at early ages tend to have larger age differences with their husbands than those who marry later, and it is more likely their marriages were arranged, often without their knowledge (Mensch, Bruce, and Greene 1998; Erulkar 2013; Lloyd 2005).

These large spousal age differences compromise a girl's agency within the marital relationship, including decisions related childbearing and family planning, as well as those related to her own body. Girls married before age 15 are often sexually initiated by force, many before they begin menstruation (Erulkar 2013). They may also enter these unions in polygamous circumstances-as junior co-wives-which further reduces their already low status. Childbearing is frequently expected after marriage, with early first births being the most risky. Girls who bear children before the age of 15 are five times more likely to die of pregnancyrelated causes compared to older mothers (Murphy and Carr 2007).

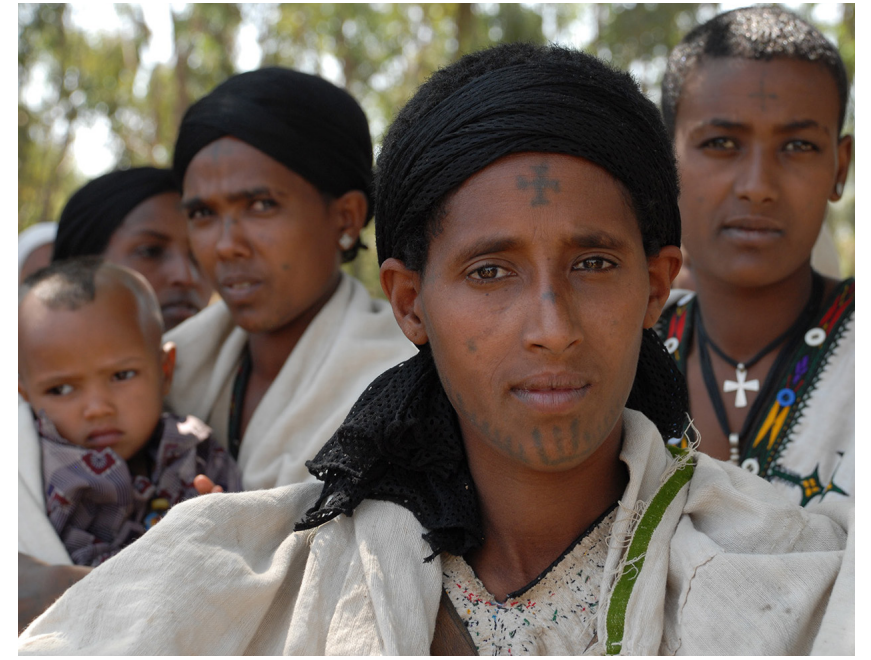

\section{BERHANE HEWAN PILOT (2004-2008): A FIRST-GENERATION INITIATIVE TO PREVENT CHILD MARRIAGE AND SUPPORT MARRIED GIRLS}

Over the last 15 years, the Population Council has conducted ground-breaking research to determine the most effective and cost-efficient strategies to reduce child marriage, through both prevention and support programs. In the early 2000s, the Ethiopia Ministry of Women Children and Youth Affairs (WCYA; formerly Ministry of Youth and Sport), the Amhara ${ }^{1}$ Regional Bureau of WCYA, the Population Council, and UNFPA collaborated on the first rigorously evaluated program in Africa with the explicit objective to delay the age of marriage and support girls who were married as children.

Berhane Hewan (meaning 'Light for Eve' in Amharic) is the name community members gave to program that targeted married and unmarried girls aged 10 to 19 in rural areas of Amhara. The intervention addressed the determinants of early marriage, including social norms, girls' lack of status and social capital, barriers to schooling, and economic factors. The

\footnotetext{
${ }^{1}$ Amhara region is the second largest region in Ethiopia and the region with the highest prevalence of child marriage.
} 
program's four components, described below, were based on formative research and consultations with communities and local leadership.

\section{STRATEGIES USED IN BERHANE HEWAN PILOT}

Community conversations to raise awareness and address cultural and social norms

Community meetings were held to discuss child marriage and other issues affecting the wellbeing of adolescent girls. 'Community conversations' use community dialogue to explore problems and devise solutions, in a community settings. Meetings include a cross-section of community members, spanning both males and females, multiple age groups, and various social roles. Community groups meet over several months and engage in collective problem-solving and follow-up action.

\section{Provision of school supplies to remain in school}

Girls who were in school, and those who wanted to return to school, were supported with school supplies such as notebooks, pens, and pencils. This was done to address the economic barriers to schooling and to take advantage of the protective effect schooling has against early marriage.

\section{Conditional asset transfer to address economic} incentives to marry girls

Families who did not marry off girls during the two-year period were promised a goat at the end of the period, jointly presented to the girl and her family. At the beginning of the project, families registered for the scheme in a public event, with household heads signing up in the presence of local leaders and other community members.

Girls' mentoring groups, including nonformal education

Female mentors who were leaders in the community led girls' groups to build skills and address social isolation and lack of social capital. Girls who were out-of-school during recruitment were encouraged to join formal school, with provision of school supplies. However, girls who were already married often did not want to join the formal school. These girls were formed into girls' groups to receive non-formal education, life skills, and mentoring.

\section{BERHANE HEWAN PILOT: SUCCESS IN DELAYING MARRIAGE AND IMPROVING SCHOOL ATTENDANCE}

Berhane Hewan included a quasi-experimental research design, with population-based surveys before and after implementation, in intervention and control sites. The results demonstrated significant changes in the status of girls. Girls aged 10 to 14 in the project area were one tenth as likely to be married compared to those in the comparison site (see Figure 1), and three times more likely to be in school. Not one girl aged 10 to 14 in the project site was married during the pilot phase. Among married girls, those residing in the Berhane Hewan project site were three times more likely to be using family planning compared to their counterparts in the control site (Erulkar and Muthengi 2009).

FIGURE 1 Percent of girls aged 10-14 who are married at baseline and endline, Berhane Hewan project site vs. control site

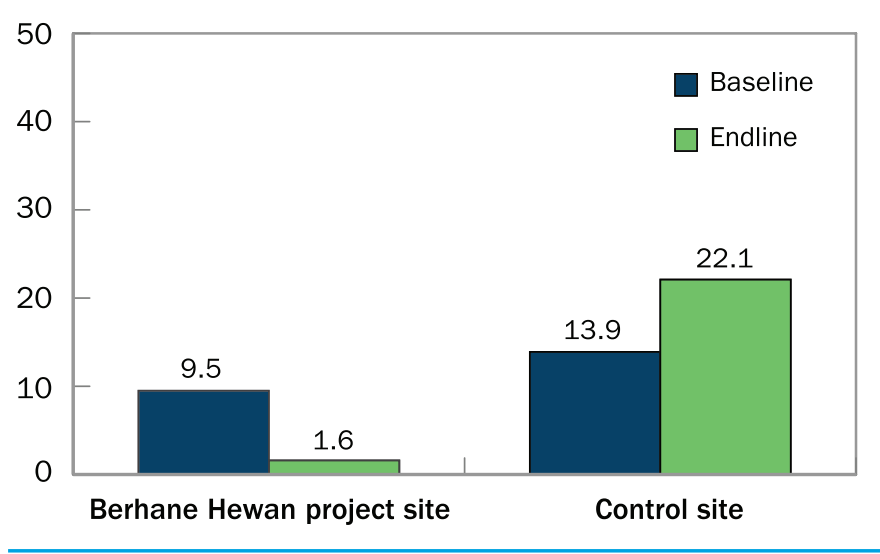

The evaluation demonstrated that it is possible to have an effect upon girls' age at marriage and school status in a relatively short period of time. Moreover, it showed that marriages to the youngest girls-below the age of 15-are extremely susceptible to being delayed. However, questions were raised as to whether the program was scalable, given the complexity of the multi-component design and the absence of cost data. Moreover, the high level of participation in all components of the project made it difficult for evaluators to ascertain which strategy was the most influential in bringing about the positive impacts witnessed.

\section{Second-Generation Evidence on Effective and Scalable Child Marriage Prevention, 2010-2016}

Building on the lessons and questions the Berhane Hewan pilot generated, the Population Council and partners initiated the second generation of work, with a view to identifying the most cost-efficient and scalable models to prevent child marriage in Africa.

In this second-generation program, partners in Ethiopia, Burkina Faso, and Tanzania are testing and costing the individual strategies used to prevent child marriage 
in the pilot phase of Berhane Hewan. Specifically, in different geographical 'hotspots' of child marriage in the three project countries, we are implementing: 1) community conversations to address social norms related to child marriage, 2) schooling support to reduce economic barriers to schooling, and 3) conditional transfers to address the economic incentives to marriage. Another geographical area includes all three models, and still another serves as a control area. Mentoring groups are not included in this phase of child marriage prevention research, since girls' groups under the Berhane Hewan pilot proved more popular among married girls than the unmarried. Registration in the three schemes requires parents to publicly register their girls in the presence of local leadership, and confirm-through signature or thumbprint-their commitment to keep girls unmarried and in school. This public registration is intended to increase accountability to commitments made.

Population-based baseline and endline surveys among girls aged 12 to 17 will measure the impact of each of the strategies on marriage age, marriage dynamics, and other reproductive health factors. The results of the study for Ethiopia and Tanzania will be available at the end of 2014; the results for Burkina Faso will be available in 2016.

The monitoring data are already yielding valuable information to contribute to cost-effective program design. Figure 2 shows the uptake of the various child marriage prevention models among Ethiopian girls in different districts, and related costs of the approaches. The uptake of the three models in Ethiopia is virtually universal, from 97 to 99 percent. $^{2}$ Registration in Tanzania and Burkina Faso is nearly as impressive: 90 to 93 percent in Tan-

2 The coverage or uptake of community conversations is not reflected since girls are not reached directly with this intervention. zania, and 88 to 99 percent in Burkina Faso. This likely reflects the local acceptability of these models as well as the willingness of families and communities to change child marriage practices, given the availability of viable alternatives and opportunities.

\section{MESERET HIWOTT: EXTENDING SUPPORT TO MARRIED GIRLS, 2008-2013}

Based on the success of married girls' groups in the Berhane Hewan pilot, the Population Council and the Amhara Regional Bureau of WCYA extended married girls' groups through a project entitled Meseret Hiwott (Amharic for "Base for Life"). Married girls aged 10 to 24 were formed into safe spaces groups and provided with HIV and reproductive health information and financial literacy, as well as skills related to communication, self-esteem, equitable gender roles, and non-violence. In parallel, a program for husbands promoted men's support of women's reproductive health, family health, and non-violent, gender-equitable relationships. Despite early skepticism that married girls would be allowed to

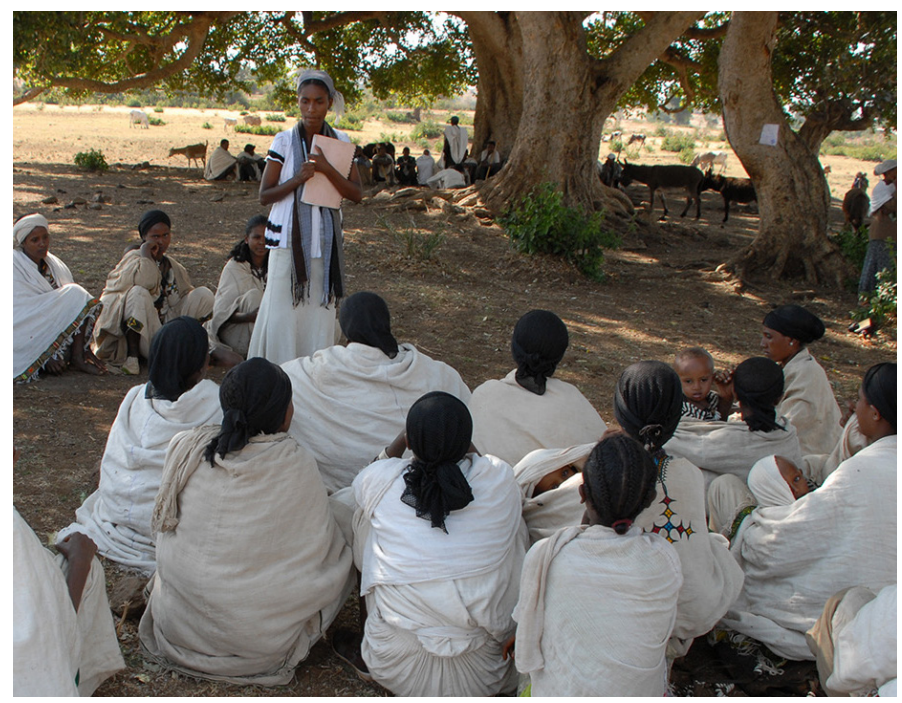

FIGURE 2 Percent of eligible girls in Ethiopia enrolling in the schemes and cost per girl, per year served

$\%$ of eligible girls enrolling in child marriage prevention schemes

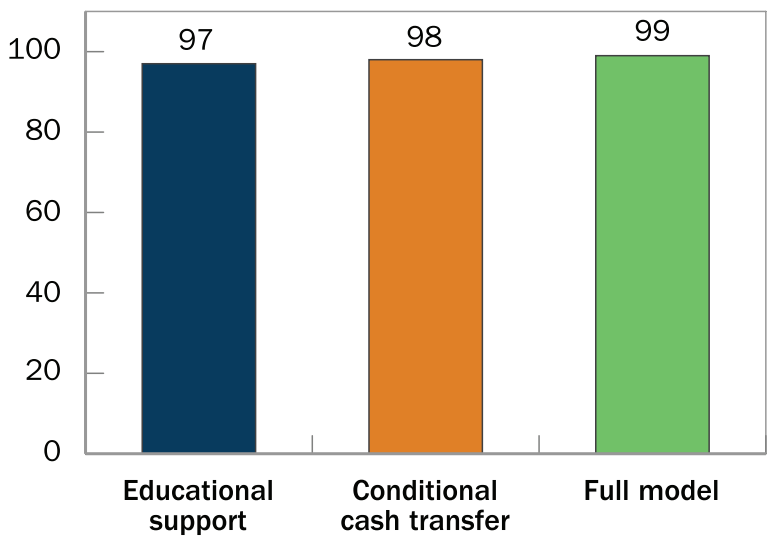

Cost per girl per year (US\$), by child marriage prevention model

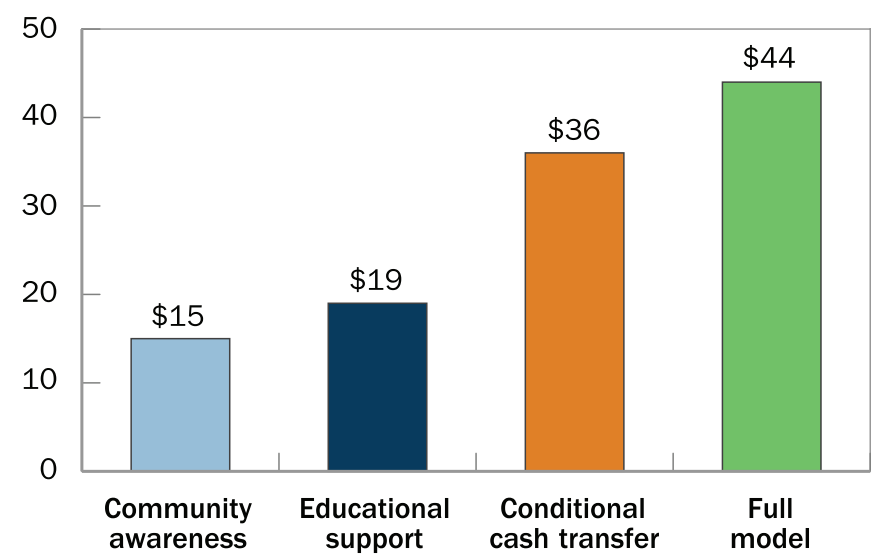

Source: Population Council analysis of service statistic and cost data. 
join groups, over 230,000 married girls and 130,000 husbands participated in the program over five years. The post-test-only evaluation demonstrated increases in husbands accompanying wives to clinics, in couples' voluntary counselling and testing (VCT), and in family planning use. Further improvements were recorded when both wives and husbands participated in the groups. For example, only 11 percent of nonparticipating couples had undergone couples' VCT, compared to 46 percent of couples whose female partner attended Meseret Hiwott, and 65 percent where both marriage partners attended the parallel groups for husbands and wives (Erulkar and Tamrat 2014).

The first- and second-generation experiences with Berhane Hewan in sub-Saharan Africa are among the first studies to rigorously test how best to prevent child marriage on the continent and support girls who are already married. Our research will inform governments and development partners on how to design minimum, scalable, cost-effective projects to delay the age at marriage and support married girls in a range of settings in Africa. Ultimately, we will apply the best available evidence and work with governments and other partners to implement and institutionalize these approaches at scale.

\section{REFERENCES}

Erulkar, A. 2013 "Very early marriage, marital relations and intimate partner violence in Ethiopia," International Perspectives on Sexual and Reproductive Health 39(1): 6-13.

Erulkar, A., E. Muthengi. 2009. "Evaluation of Berhane Hewan: A program to delay marriage in rural Ethiopia," International Perspectives on Sexual and Reproductive Health 35(1): 6-14.

Erulkar, A., T. Tamrat. 2014. "Evaluation of reproductive health programs to support married adolescent girls and their husbands in rural Ethiopia," African Journal of Reproductive Health 18(2): 68-76.

Lloyd, C, ed. 2005. Growing Up Global: Changing Transitions to Adulthood in Developing Countries. Washington, DC: National Academies Press.

Mensch, B., J. Bruce, M. Greene. 1998. The Uncharted Passage: Girls' Adolescence in the Developing World. New York: Population Council.

Murphy, E., D. Carr. 2007. "Powerful partners: Adolescent girls' education and delayed childbearing," Brief. Washington, DC: Population Reference Bureau.
${ }^{6} 6_{\text {We girls were put under family pressure, so }}$ we did not attend school. We were forced to marry. If we get school supplies like exercise books and pens, our family does not have this expense. In my family, there are a lot of children so my parents couldn't provide school supplies. But now the project bought me exercise books... Once a girl is enrolled in school, her parents cannot force her to marry. 99

-ETHIOPIAN GIRL, EDUCATIONAL SUPPORT

United Nations Population Fund (UNFPA). 2005. State of the World Population. New York: UNFPA.

United National Children's Fund (UNICEF). 2001. "Early marriage: Child spouses." Florence, Italy, UNICEF.

. 2011. State of the World's Children 2011: Adolescence, An age of Opportunity. New York: UNICEF.

\section{PARTNERS}

Amhara Regional Bureau of Women, Children and Youth Affairs Association Munyu des Femmes de la Comoé Ethiopia Ministry of Women, Children and Youth Affairs Ministère de l'Action Sociale du Burkina Faso National Institute for Medical Research, Tanzania Tabora Development Foundation Trust

\section{DONORS}

Nike Foundation

United Nations Foundation

UNFPA

USAID-PEPFAR

USAID-Washington

For more information, please contact:

Dr. Annabel Erulkar

Country Director

Population Council

P.O. Box 25562,

Code 1000

Addis Ababa, ETHIOPIA

aerulkar@popcouncil.org 